$11-12-1993$

\title{
Care for Those Who Wore the Uniform
}

Kenneth Lasson

University of Baltimore School of Law, klasson@ubalt.edu

Follow this and additional works at: http://scholarworks.law.ubalt.edu/all_fac

Part of the Military, War, and Peace Commons, and the Social Welfare Law Commons

\section{Recommended Citation}

Care for Those Who Wore the Uniform, The Baltimore Sun, November 12, 1993

This Editorial is brought to you for free and open access by the Faculty Scholarship at ScholarWorks@University of Baltimore School of Law. It has been accepted for inclusion in All Faculty Scholarship by an authorized administrator of ScholarWorks@University of Baltimore School of Law. For more information, please contact snolan@ubalt.edu. 


\section{Related Articles}

'On Behalf of a Grateful Country...'

September 14, 2003

Veterans brace for impact of budget cuts

May 23, 1995

Veteran's essay on killing

November 21, 2010

Service dog warns veteran of coming seizures March 25, 2011

\section{Find More Stories About}

Pensions

Revolutionary War

\section{Care for Those Who Wore the Uniform}

November 12, 1993 | By KENNETH LASSON

KENNETH LASSON

Done give myself to Uncle Sam,

Now I ain't worth a good goddam.

-- American spiritual

It's a sad fact that a third of America's homeless population are veterans. More poignant still, the vast majority of all those who come to Veterans Administration hospitals are indigent or have disabilities related to their military service.

None of this is especially new. Throughout history armies have been kept, wars waged, soldiers have died and veterans come marching home. Not always, however, have warriors returning from lost battles been welcomed with open arms -especially in the era of conscripted military forces and unpopular conflicts -- and not always have the victors reaped the spoils.

Say what you will about Bill Clinton's own non-involvement in the Vietnam War, both his economic-stimulus program and his health-care plan sustain a time-honored tradition to take care of everyone who's ever worn a uniform in service to the country.

Considerations were granted to American war veterans as far back as 1636, when the pilgrims, in the midst of an Indian insurrection, devised a special law providing rights and assistance to those who fought. Various of the early American colonies passed similar laws for disabled veterans, and by the time of the Revolution the benefits concept had been firmly established.

American officers during the Revolutionary War found themselves naturally disposed to the established tradition of their British counterparts: the king's soldiers were awarded half-pay for life upon the completion of their military service. George Washington had held out the promise of pensions as inducements to enlist in the fledgling army, and as the war itself was being fought the Continental Congress had passed various measures in that direction. The last of these provided for a payment to veteran officers of five years' full wages, in the form of government-issued securities.

After the Revolution the issue of pensions remained hotly contested, primarily because the measures discriminated against enlisted men (in favor of officers) and because many citizens were opposed to increasing the already high costs of war.

In those days government spending was, to say the least, different: In 1818 Congress found itself with a budget surplus! The immediate beneficiaries of the legislative largess that soon followed were all persons who had served for nine months or longer during the Revolutionary War, and who could demonstrate financial need. By 1836 the pension program had been enlarged to include all dependents of veteran soldiers.

It still wasn't much. "A soldier has a hard life," said Robert E. Lee in 1855, "but little consideration." Medical benefits for veterans were not instituted until 1861, when a "hometown" treatment program was devised, and in 1865 the National Home for Disabled Volunteer Soldiers -- actually a network of facilities throughout the country -- was established.

It was another half-century, though, before major grants were given for the first time as disability compensation -- mainly to meet the needs of World War I veterans. Congress established various agencies to administer the benefits, such as the old Bureau of War Risk Insurance, the Federal Board for Vocational Rehabilitation, and eventually the Public Health Service.

Said Calvin Coolidge in 1920: "The nation which forgets its defenders will itself be forgotten." But such platitudes did little to solve the fragmented adminstration of veterans' affairs, which inevitably was overwhelmed by the sheer volume of cases. Thus was established, in 1930, the Veterans Administration. Even at its creation the new agency had a budget of $\$ 641$ million and a staff of 31,500 people, serving roughly 4.7 million living veterans.

Today the annual budget of the VA is more than $\$ 20$ billion, processed by some 250,000 public servants. There are about 25 million veterans, whose dependents may be three times that number. The VA runs 171 medical centers, 132 nursing-home units and more than 30 clinics. It is a world leader in the treatment of spinal-cord injuries and posttraumatic stress disorders, rehabilitation of the blind and care of the elderly.

Much of the dissatisfaction with the VA stems from its needlessly complex array of eligibility rules. Its shortcomings are not with the quality of its services, but the inability to deliver more of them.

All this would change under the president's proposed reforms. At least that aspect of them deserves our support, if for no other reason than to honor our veterans by taking care of them.

Kenneth Lasson is a law professor at the University of Baltimore.

\section{MORE:}

Minor's future arrives early Rookie didn't expect to make 


\section{a start at third this season \\ Why expansion tank is needed \\ How to treat bone spurs}

Senator's wife recounts terror, helplessness as victim of obsessed stalker

Ga. Tech's Peacock suspended

Ravens tackle Michael Oher takes big brother job seriously 